\title{
Analysis of the Policy Text of Entrepreneurship Education in Chinese Colleges and Universities (1998-2019)
}

\author{
Dai Yan \\ School of Public Affairs, University of Science and Technology of China, Hefei, China \\ Email: daiyan7719@sina.com
}

How to cite this paper: Yan, D. (2020). Analysis of the Policy Text of Entrepreneurship Education in Chinese Colleges and Universities (1998-2019). Open Journal of Social Sciences, 8, 218-231.

https://doi.org/10.4236/jss.2020.87018

Received: June 30, 2020

Accepted: July 19, 2020

Published: July 22, 2020

Copyright $\odot 2020$ by author(s) and Scientific Research Publishing Inc. This work is licensed under the Creative Commons Attribution International License (CC BY 4.0).

http://creativecommons.org/licenses/by/4.0/

\begin{abstract}
In this paper, the policy text of entrepreneurship education in Chinese colleges and universities from 1998 to 2019 is sorted out, and the grounded theory is adopted to analyze the content of the text. The result shows that China has established a relatively complete policy system after undergoing over two decades of development. Four types of policies have been formed: capacitybuilding policies, entrepreneurial incubation policies, faculty incentive policies and environment optimization policies, which have played a great part in promoting the development of entrepreneurship education in Chinese colleges and universities. To better serve China's economic and social needs, the government should further leverage the policy benefits, and guide the formation of a community of shared interests of entrepreneurship education in colleges and universities in a wider range of fields through policies, so as to revitalize the existing resources of entrepreneurship education, and encourage teachers to carry out entrepreneurship education activities continuously and steadily.
\end{abstract}

\section{Keywords}

Entrepreneurship Education, Policy, Text Analysis

\section{Introduction}

Led and guided by the entrepreneurship education policy over the past 20 years, Chinese colleges and universities have conducted useful explorations on the theory and practice of entrepreneurship education and yielded impressive results (Dong, 2012). The policy of entrepreneurship education in Chinese colleges and universities constitutes a vital part of the entrepreneurship education ecosystem in col- 
leges and universities, and also greatly contributes to its development and operation. Therefore, it is of great theoretical significance and practical value to explore the evolution rule and development trend of the policy system (Xue, 2018). China started entrepreneurship education in the field of higher education relatively late than European and American countries, but it develops rapidly, yields rich educational achievements and involves a wide range of groups, which benefits from a series of policies on entrepreneurship education in colleges and universities issued by the Chinese government.

The policy is essentially an action plan with normative intention, through which the constituent elements of the policy are arranged to achieve specific goals, values and interests (Zhu, 2018). Since 1998, the State Council, the Ministry of Education and other departments have implemented incentives to entrepreneurship education in colleges and universities through various ways including policies and measures, notification documents, and activity projects, so as to provide environmental support for the start of entrepreneurship education in colleges and universities.

As China's national innovation strategy develops, entrepreneurship education in Chinese colleges and universities must speed up the transformation from following behind, and running with the crow to taking the lead, which implies a further optimization required for the policy system of entrepreneurship education in colleges and universities. This paper makes a scientific and in-depth analysis of the policy text of entrepreneurship education in Chinese colleges and universities since 1998, and clarifies the mode and point of action of the policy of entrepreneurship education in colleges and universities. Based on analyzing the evolution rule of entrepreneurship education policy, relevant suggestions are put forward on optimizing the entrepreneurship education policy in Chinese colleges and universities.

\section{Research Design}

\subsection{Research Methods}

The grounded theory (Glaser \& Strauss, 1967) was first proposed by Barney Glaser of the University of Chicago and Anselm Strauss of Columbia University in 1967. The researchers put aside the pre-theoretical interference, obtain the data of the research object, and form the concept by repeatedly comparing and extracting the phenomenon with common characteristics through the method of content analysis. The researchers always keep the synchronous reciprocating between the data collection and the data analysis (Gephart, 2004) the core feature of which is "to establish a theory on the basis of empirical data" (Chen, 1999).

\subsection{Research Data}

Launched in 1998, the entrepreneurship education in Chinese colleges and universities underwent about 4 years of deepening and has stepped into the comprehensive promotion stage since 2012. With the release of the Opinions of the 
General Office of the State Council in 2015, various policy documents related to entrepreneurship education in colleges and universities have been issued continuously. For better understanding the policy impact of entrepreneurship education in Chinese colleges and universities, the data in this paper is determined as starting in 1998 and ending in July 2019.

The institutional theory deems that the institutional environment will bring three types of pressure to the organization: mandatory pressure, normative pressure and imitative pressure (Krücken, 2017), in which mandatory pressure means to ask the organization to provide a certain kind of behavior through formal decrees and rules. In this way, mandatory pressure guides the activities of the organization and shapes its culture. In terms of specific forms, mandatory pressure includes laws and regulations, policies promulgated by governments at all levels, etc.; normative pressure is usually manifested as experience, criteria, standards, etc., which is the action standard and basis for the organization to abide by; imitative pressure means that in the case of vague objectives and uncertain action plan of the organization, the organization alleviates its pressure by imitating the action of other organizations when it feels the pressure from the development of other organizations. Under the pressure, the institutional theory also proposes from the perspective of organizational sociology that in the scope of the social system, organizations will gain legitimacy by actively providing socially desirable and appropriate behavior. Organizational sociology points out that the institutional environment includes three aspects: management system, normative system and cognitive system (Scott, 1995), of which the management system refers to some laws, regulations and government policies that promote or restrict specific behavior (Busenitz et al., 2000).

The ultimate goal of entrepreneurship education in colleges and universities is to educate people utilizing various activities centering on entrepreneurship, which, from the experience at home and abroad, includes courses, programs, competitions and practical activities. In combination with the content of the institutional theory, this paper holds that in every link of entrepreneurship education, the policies, measures and regulations of various ministries and commissions in the construction process of education and evaluation system, curriculum system, practical training and research programs, practice platform and other software and hardware facilities, supporting funds and resources, achievement identification standards, transformation process and benefit distribution are the investigation objects of this study.

To be specific, it includes the following categories: administrative regulations, rules and regulations, opinions and suggestions issued by the State Council and the departments and commissions under the CPC Central Committee. See Table 1 for details.

\subsection{Methods of Obtaining Research Data}

The source of this paper includes two retrievals on the official websites of the 
Table 1. Types of policies related to entrepreneurship education in colleges and universities.

\begin{tabular}{cc}
\hline Level of issuing authority & Type \\
$\begin{array}{c}\text { Ministries and commissions of the state and } \\
\text { departments and commissions under the } \\
\text { CPC Central Committe }\end{array}$ & Policy, notice, proposal, method \\
Local governments and related departments & $\begin{array}{c}\text { Policy, action plan, opinion, method } \\
\text { Colleges and universities }\end{array}$ \\
The training program, annual assessment, \\
career advancement, software and \\
hardware projects, etc.
\end{tabular}

State Council, the Ministry of Education, the Ministry of Human Resources and Social Security, the Ministry of Science and Technology and other ministries, as well as platforms such as Chinalawinfo. The first retrieval was carried out with "entrepreneurship" as the subject word, followed by the second retrieval with "university students" or "college and university" as the subject words on the results of the first retrieval results. As a result of the comprehensive search, 189 relevant policy texts were obtained. Excluding the overlapping content and the parts that are not consistent with the research topic, a total of 121 policy texts are retained, of which 48 are jointly issued, accounting for $46 \%$ of the total. See Table 2 for the details of the issuance of various ministries and commissions are.

\section{Research Process}

\subsection{Preliminary Analysis of the Policy Text Data of Entrepreneurship Education in Colleges and Universities}

The data collected in this study show that the State Council and 13 departments and commissions under the CPC Central Committee have issued documents closely related to entrepreneurship education in colleges and universities since 1998, among which the State Council, the Ministry of Education and the Ministry of Human Resources and Social Security have the largest number of independent issuance. It means that entrepreneurship education in Chinese colleges and universities is implemented and promoted by the Ministry of Education, the Ministry of Human Resources and Social Security under the leadership of the State Council, with other ministries and commissions playing a coordination and support role, as shown in Figure 1.

Judging from the distribution of the above issuing time, there are four stages of changes in the issuing of entrepreneurial policies of colleges and universities by governments at all levels in China: 1) Gradual issuance period. From 1998 to 2005 , the number of policy texts kept at an annual average of 1, which was stable on the whole; 2) Stable issuance period. From 2005 to 2012, the issued policy texts saw a stable promotion. Except for some periods with relatively prominent issuance, the number of issuances is not significantly different in other years; 3 ) Steady growth period. It can be seen from the chart that from 2012 to 2015, the 
Table 2. Departments issuing policies related to entrepreneurship education in colleges and universities and their distribution.

\begin{tabular}{|c|c|c|c|c|c|}
\hline $\begin{array}{c}\text { Issuing } \\
\text { department }\end{array}$ & $\begin{array}{l}\text { Number of } \\
\text { issuances }\end{array}$ & $\begin{array}{l}\text { Number } \\
\text { of joint } \\
\text { issuances }\end{array}$ & $\begin{array}{c}\text { Issuing } \\
\text { department }\end{array}$ & $\begin{array}{l}\text { Number of } \\
\text { issuances }\end{array}$ & $\begin{array}{l}\text { Number } \\
\text { of joint } \\
\text { issuances }\end{array}$ \\
\hline State Council & 15 & 0 & $\begin{array}{l}\text { Ministry of Science } \\
\text { and Technology }\end{array}$ & 6 & 4 \\
\hline $\begin{array}{l}\text { Ministry of } \\
\text { Education }\end{array}$ & 24 & 5 & $\begin{array}{c}\text { Publicity Department } \\
\text { of the CPC Central } \\
\text { Committee }\end{array}$ & 1 & 1 \\
\hline Ministry of Human & & & National Intellectual & & \\
\hline $\begin{array}{l}\text { Resources and } \\
\text { Social Security }\end{array}$ & 13 & 8 & $\begin{array}{c}\text { Property } \\
\text { Administration }\end{array}$ & 1 & 1 \\
\hline $\begin{array}{l}\text { Ministry of } \\
\text { Finance }\end{array}$ & 4 & 4 & $\begin{array}{l}\text { Ministry of Industry } \\
\text { and Information } \\
\text { Technology }\end{array}$ & 3 & 3 \\
\hline $\begin{array}{l}\text { National } \\
\text { Development } \\
\text { and Reform } \\
\text { Commission }\end{array}$ & 2 & 2 & $\begin{array}{l}\text { Organization } \\
\text { Department of } \\
\text { the CPC Central } \\
\text { Committee }\end{array}$ & 2 & 2 \\
\hline $\begin{array}{l}\text { Communist } \\
\text { Youth League }\end{array}$ & 7 & 3 & $\begin{array}{l}\text { State Commission } \\
\text { Office of Public } \\
\text { Sectors Reform }\end{array}$ & 1 & 1 \\
\hline $\begin{array}{l}\text { Ministry of } \\
\text { Civil Affairs }\end{array}$ & 1 & 1 & $\begin{array}{l}\text { State Taxation } \\
\text { Administration }\end{array}$ & 3 & 3 \\
\hline
\end{tabular}

Note: Repeated issuance of documents of the same kind in different years is counted as one time.

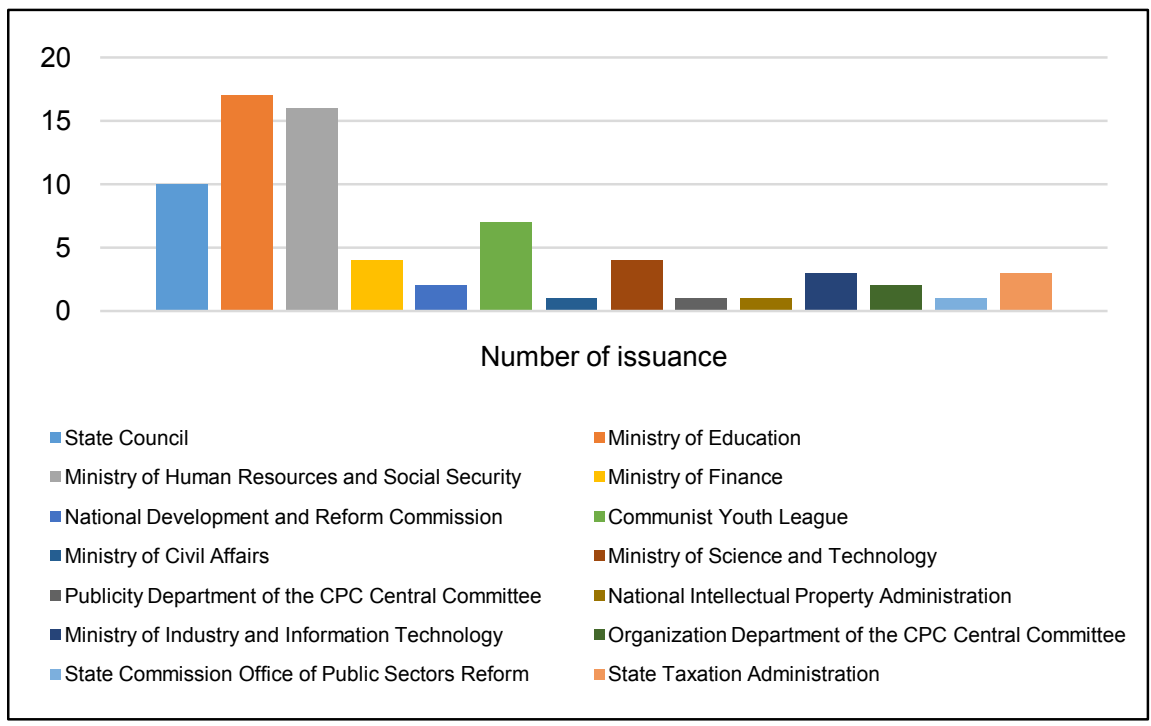

Figure 1. Distribution chart of departments issuing policies related to entrepreneurship education in colleges and universities (departments and commissions under the CPC Central Committee). 
number of policy texts issued by governments at all levels began to increase, especially in 2012; 4) Rapid growth period. The issued policy texts have soared since 2015, particularly in 2015 and 2016, as detailed in Figure 2.

As per the number of issuances, the issuing of entrepreneurship education policies in Chinese colleges and universities can be divided into four periods: gradual issuance period, stable issuance period, steady growth period and rapid growth period, which are basically consistent with the development process of entrepreneurship education practice in colleges and universities.

Obviously, the government plays a vital role in promoting the development of entrepreneurship education in Chinese colleges and universities. The launching and development of entrepreneurship education in colleges and universities has always been led by the State Council, managed by the Ministry of Education and the Ministry of Human Resources and Social Security, and followed up by local governments. The government directly participates in the construction of entrepreneurship education in colleges and universities by issuing policies and measures; colleges and universities feed back the exploration experience and model of entrepreneurship education to the government, which turns into the basis of a new round of policies. This kind of reciprocation enables the entrepreneurship education system in Chinese colleges and universities to complete the construction process from exploration, discovery, and popularization to deepening. This process involves an increasing number of government departments, colleges and universities, and cooperative subjects.

\subsection{In-Depth Analysis of the Policy Text Data of Entrepreneurship Education in Colleges and Universities}

\subsubsection{Open Coding}

To ensure the effectiveness and representativeness of the policy texts used for analysis, this paper screens the policy texts and eliminates 15 similar notices such as entrepreneurship competitions and projects in colleges and universities issued by various ministries and local relevant departments every year. After

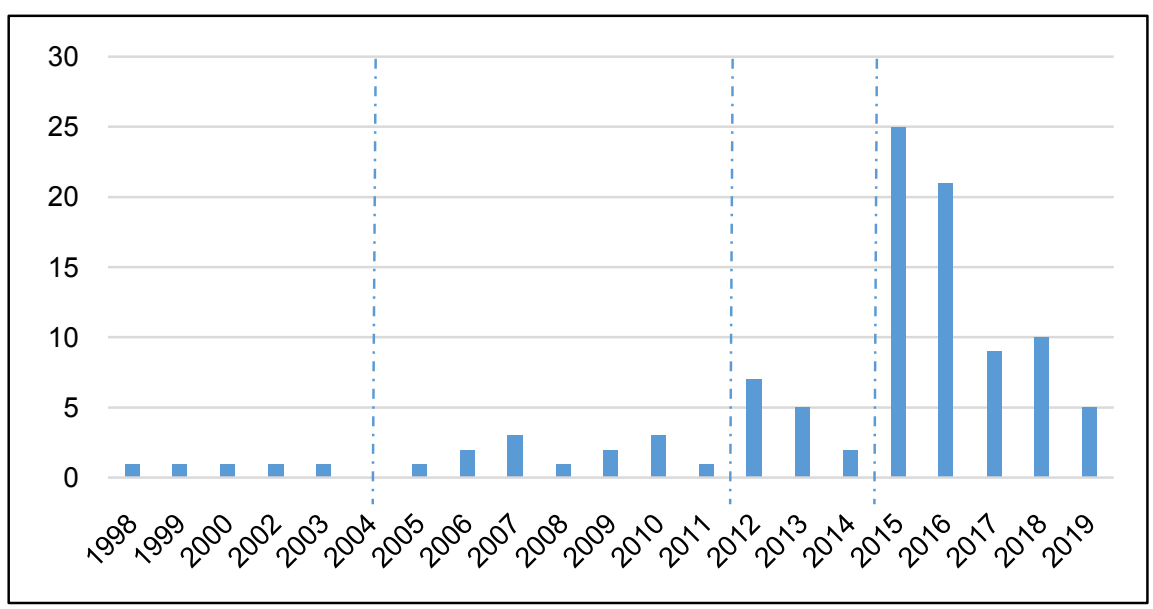

Figure 2. Annual distribution chart of various government policy texts. 
screening, a total of 78 texts such as policies and measures that affect teachers in colleges and universities to engage in entrepreneurship education are sorted out for in-depth text analysis.

\section{1) Conceptualization}

In this study, three types of data are interpreted, marked and extracted line by line. To keep the consistency with Chapters 3 and 4, the code of this chapter is represented by $\mathrm{c} 1, \mathrm{c} 2, \mathrm{c} 3 \ldots$, and the category is represented by $\mathrm{C} 1, \mathrm{C} 2$ and $\mathrm{C} 3 . .$. See Table 3 and Table 4 for details.

This paper reads the policy texts related to entrepreneurship education in colleges and universities and extracts the $\mathrm{c} 1$ - c96 codes by line-by-line coding. The whole process is carried out by mutual verification of team members. The code with different opinions can be used only after reaching an agreement through discussion, in preparation for the next step of categorization.

\section{2) Categorization}

In this study, the category is established as per the specific content of the codes. First, the concepts of the same kind are merged by categories, then the

Table 3. Conceptualization of open coding (government) (excerpt).

\begin{tabular}{|c|c|}
\hline Original text & Coding \\
\hline $\begin{array}{l}\text { State Council (1999): "strengthen entrepreneurship } \\
\text { education for teachers and students... and encourage } \\
\text { them to set up high-tech enterprises on their own" }\end{array}$ & $\begin{array}{c}\text { Strengthening entrepreneurship } \\
\text { education } \mathrm{cl}\end{array}$ \\
\hline $\begin{array}{c}\text { Ministry of Education (2002): "summarize and exchange } \\
\text { the experience of conducting entrepreneurship } \\
\text { education in schools over the past year" }\end{array}$ & $\begin{array}{l}\text { Promoting exchanges and } \\
\text { exploration among colleges } \\
\text { and universities c2 }\end{array}$ \\
\hline $\begin{array}{c}\text { Ministry of Education (2008): "China Association of Higher } \\
\text { Education has specially initiated the 'Research on the Theory } \\
\text { and Development of Innovation and Entrepreneurship } \\
\text { Education in Chinese Colleges and Universities' as a } \\
\text { key special planning project of 2008" }\end{array}$ & $\begin{array}{l}\text { Special scientific research } \\
\text { on entrepreneurship } \\
\text { education } \mathrm{c} 3\end{array}$ \\
\hline $\begin{array}{l}\text { Ministry of Education (2008): “100 innovative experimental } \\
\text { zones for talent training model”, “ } 500,000 \text { yuan for each } \\
\text { experimental zone, which will be allocated annually, } \\
\text { with the first tranche of } 200,000 \text { yuan" }\end{array}$ & $\begin{array}{c}\text { Establishing innovative } \\
\text { experimental zone c4,500,000 } \\
\text { yuan to support the experimental } \\
\text { zone c5, funds are allocated } \\
\text { annually c6 }\end{array}$ \\
\hline $\begin{array}{l}\text { Ministry of Education (2017): "teach to build a national } \\
\text { talent pool of 10,000 outstanding innovative and } \\
\text { entrepreneurial mentors based on the talent pool of } \\
\text { innovative and entrepreneurial mentors in colleges } \\
\text { and universities across the country" }\end{array}$ & $\begin{array}{l}\text { Building a talent pool } \\
\text { for mentors } \mathrm{c} 71\end{array}$ \\
\hline $\begin{array}{l}\text { Ministry of Education (2018): “emphasize the promotion } \\
\text { of construction and innovation; high-quality courses in } \\
\text { entrepreneurship education, to enhance teachers' ability } \\
\text { of innovation and entrepreneurship education and } \\
\text { carry out 'Youth Red Dream Building Tour”” }\end{array}$ & $\begin{array}{l}\text { Establishing entrepreneurship } \\
\text { course c86, enhancing young } \\
\text { teachers' educational ability c87 }\end{array}$ \\
\hline
\end{tabular}


Table 4. Open coding-category table (government) (excerpt).

\begin{tabular}{|c|c|}
\hline Concept & Category \\
\hline $\begin{array}{l}\text { Covering colleges and universities nationwide c72, submitting } \\
\text { the implementation plan of entrepreneurship education to the } \\
\text { Ministry of Education c34, formulating the action schedule of } \\
\text { entrepreneurship education c36, setting up the steering } \\
\text { committee of entrepreneurship education } c 29 \text {, }\end{array}$ & $\begin{array}{l}\text { Entrepreneurship education } \\
\text { popularization } \mathrm{C} 1\end{array}$ \\
\hline $\begin{array}{l}\text { Enhancing young teachers' educational ability c86, } \\
\text { build a talent pool of mentors c70, }\end{array}$ & Faculty cultivation $\mathrm{C} 2$ \\
\hline $\begin{array}{l}\text { establishing the designated institution of entrepreneurship } \\
\text { training in colleges and universities c32, attaching importance } \\
\text { to the educational value of entrepreneurship practice c14 }\end{array}$ & $\begin{array}{l}\text { Building practice } \\
\text { base } \mathrm{C} 3\end{array}$ \\
\hline $\begin{array}{l}\text { Establishing entrepreneurship course } c 85 \text {, } \\
\text { establishing high-quality open course c46, }\end{array}$ & $\begin{array}{l}\text { Increasing entrepreneurship } \\
\text { course } \mathrm{C} 4\end{array}$ \\
\hline Compiling entrepreneurship education textbook c45 & $\begin{array}{l}\text { Compiling related } \\
\text { textbook C5 }\end{array}$ \\
\hline $\begin{array}{l}\text { Productive internship c79, encouraging teachers } \\
\text { to increase social practice c64 }\end{array}$ & Practical ability exercise C6 \\
\hline Reforming the way of academic evaluation $c 47$ & $\begin{array}{l}\text { Academic evaluation } \\
\text { reform C7 }\end{array}$ \\
\hline $\begin{array}{l}\text { Carrying out entrepreneurship teaching } \\
\text { by classification c } 30\end{array}$ & $\begin{array}{c}\text { Classified } \\
\text { management C8 }\end{array}$ \\
\hline $\begin{array}{l}\text { Constructing hardware facilities conducive } \\
\text { to entrepreneurship education } c 48\end{array}$ & $\begin{array}{l}\text { Teaching hardware } \\
\text { facilities C9 }\end{array}$ \\
\hline $\begin{array}{c}\text { Recommending scientific research projects in colleges and } \\
\text { universities c44, special scientific research of } \\
\text { entrepreneurship education c3 }\end{array}$ & $\begin{array}{l}\text { Entrepreneurship theme } \\
\text { scientific research } \mathrm{C} 10\end{array}$ \\
\hline $\begin{array}{l}\text { Achievements of researchers participating in entrepreneurship } \\
\text { used in job competition c89, professional title evaluation, } \\
\text { etc. c90, peer evaluation c57, representative achievement } \\
\text { evaluation c58, }\end{array}$ & $\begin{array}{l}\text { Reform of assessment } \\
\text { and promotion } \mathrm{C} 11\end{array}$ \\
\hline $\begin{array}{l}\text { Scientific and technological achievements transformation reward c68, } \\
\text { reward for individuals without affecting the entity c69, promoting } \\
\text { the transformation of scientific research achievements c63 }\end{array}$ & $\begin{array}{l}\text { Increasing teachers' } \\
\text { return on } \\
\text { achievements } \mathrm{C} 12\end{array}$ \\
\hline $\begin{array}{c}\text { Encouraging researchers to leave their posts to start their own } \\
\text { businesses c88, protecting the legitimate rights and interests } \\
\text { of those who have left their posts c } 89\end{array}$ & $\begin{array}{l}\text { Motivating teachers' } \\
\text { entrepreneurial } \\
\text { action } \mathrm{C} 13\end{array}$ \\
\hline $\begin{array}{l}\text { Preferential tax for start-ups c82, } \\
\text { fee reduction and exemption c19 }\end{array}$ & $\begin{array}{l}\text { Tax reduction and exemption } \\
\text { and subsidy } \mathrm{C} 14\end{array}$ \\
\hline $\begin{array}{l}\text { Issuing self-employment certificate } c 26, \mathrm{R} \& \mathrm{D} \text { expenses included } \\
\text { in the current loss } c 81 \text {, lowering market access threshold } c 18\end{array}$ & $\begin{array}{l}\text { Reducing entrepreneurial } \\
\text { obstacles C15 }\end{array}$ \\
\hline $\begin{array}{l}\text { Setting up entrepreneurship education credits c52, establishing } \\
\text { credit accumulation and conversion system c53 }\end{array}$ & $\begin{array}{l}\text { Institutional } \\
\text { guarantee } \mathrm{C} 16\end{array}$ \\
\hline
\end{tabular}




\section{Continued}

Petty loan c20, venture fund c21, setting up entrepreneurship scholarship c55, launching national large-scale entrepreneurship project c31, providing entrepreneurship support fund c24

Entrepreneurial mentor system c73, establishing mentor talent pool c70

Intellectual support $\mathrm{C} 18$

Facilitating entrepreneurial premise $\mathrm{c} 17$, the incubator for supporting university students to start a business c16

Establishing intellectual property trading platform c84

Hardware support C19

Property rights protection $\mathrm{C} 20$

Adjusting the structure c94, making up for the deficiency c95, gathering resources for entrepreneurship c96, business environment c97

Economic structure adjustment $\mathrm{C} 21$

Uniting enterprises to build entrepreneurship education platform c49, platform to integrate resources $\mathrm{c15}$, interdisciplinary education $\mathrm{c} 43$

Resource sharing mechanism $\mathrm{C} 22$

University-local government cooperation mechanism c39, university-research institution cooperation mechanism, promoting exchanges and exploration between colleges and universities c2

merger results are abstracted and condensed again, and finally 23 categories are obtained. These 23 categories include entrepreneurship education popularization, faculty cultivation, building practice base, compiling related textbook, increasing entrepreneurship course, academic evaluation reform, practical ability exercise, classified management, teaching hardware facilities, entrepreneurship theme scientific research, reform of assessment and promotion, increasing teachers' return on achievements, motivating teachers' entrepreneurial action, tax reduction and exemption and subsidy, reducing entrepreneurial obstacles, institutional guarantee, financial support, intellectual support, hardware support, property rights protection, economic structure adjustment, resource sharing mechanism, and action coordination mechanism.

\subsubsection{Axial coding}

This study extracts C1 - C23 categories from c1 - c96 codes, and these 23 categories include entrepreneurship education popularization, faculty cultivation, building practice base, increasing entrepreneurship course, compiling related textbook, practical ability exercise, academic evaluation reform, classified management, teaching hardware facilities, entrepreneurship theme scientific research, reform of assessment and promotion, increasing teachers' return on achievements, motivating teachers' entrepreneurial action, tax reduction and exemption and subsidy, reducing entrepreneurial obstacles, institutional guarantee, financial support, intellectual support, hardware support, property rights protection, economic structure adjustment, resource sharing mechanism, and action coordination mechanism. This paper mergers these 23 categories to obtain four types 
of policies: capacity building policies (including entrepreneurship education popularization, faculty cultivation, building practice base, increasing entrepreneurship course, compiling related textbook, practical ability exercise, academic evaluation reform, classified management, and teaching hardware facilities), entrepreneurial incubation policies (including tax reduction and exemption and subsidy, reducing entrepreneurial obstacles, institutional guarantee, financial support, intellectual support, and hardware support), faculty incentive policies (including carrying out thematic scientific research, reform of assessment and promotion, increasing teachers' return on achievements, and motivating teachers' entrepreneurial action), and environment optimization policies (including property rights protection, economic structure adjustment, resource sharing mechanism, and action coordination mechanism). See Table 5 for details.

\section{Research Conclusion and Recommendations}

On the whole, capacity building and entrepreneurial incubation policies occupy the most part. Among them, the capacity-building policies include 9 sub-items, of which the course construction is the most prominent, with 43 texts mentioning the construction of entrepreneurial courses. The entrepreneurial incubation policies include 6 sub-items, of which the financial guarantee is most valued. Faculty incentive policies emerged in the past three years thanks to the Opinions on Deepening the Reform of Talent Development Systems and Mechanisms issued by the CPC Central Committee in 2016. Concerning the environment optimization policies, policy texts attach increasing Importance to the protection and management of intellectual property rights and the construction of a collaborative education mechanism.

1) The policies feature continuity, and the number of joint issuances is increasing year by year, accounting for about $46 \%$ of the total

The focus of this paper changes with time, with attention to the optimization of entrepreneurship education environment in the early stage, more attention to the incentive for action in recent times, and attention to the evaluation of the output of action results in the last two years. Judging from the text number sort out in this paper, the proportion of joint issuance by various departments has increased year by year, accounting for about $46 \%$ of the total. It shows that the government is giving increasing weight to the value of collaborative education mechanism and collaborative platform in driving the high-quality development of entrepreneurship education in colleges and universities. However, there is not enough policy on further improving and optimizing the ecology of entrepreneurship education in colleges and universities by virtue of market forces. As per the triple helix theory, the optimization of entrepreneurship education in colleges and universities "must pursue the benign interaction among universities, governments and enterprises" (Etzkowitz, 2008). Combined with the analysis results of the policy text and the needs of China's social development, the government should significantly increase the policies and measures targeted at enterprises 
Table 5. Policy text analysis axial coding table (excerpt).

\begin{tabular}{|c|c|c|}
\hline Main category & Category & Concept (excerpt) \\
\hline & $\begin{array}{l}\text { Entrepreneurship } \\
\text { education } \\
\text { popularization } \mathrm{C} 1\end{array}$ & $\begin{array}{l}\text { Covering colleges and universities nationwide } \\
\text { c72, submitting the implementation plan of } \\
\text { entrepreneurship education to the Ministry of } \\
\text { Education c34, formulating the action schedule } \\
\text { of entrepreneurship education c36, }\end{array}$ \\
\hline & $\begin{array}{c}\text { Faculty } \\
\text { cultivation C2 }\end{array}$ & $\begin{array}{l}\text { Enhancing young teachers' educational ability } \\
\text { c86, cultivating lecturers for entrepreneurship } \\
\text { training theory course c } 33\end{array}$ \\
\hline & $\begin{array}{l}\text { Building practice } \\
\text { base } \mathrm{C} 3\end{array}$ & $\begin{array}{l}\text { establishing the designated institution of } \\
\text { entrepreneurship training in colleges and } \\
\text { universities c32, rewarding the training base } \\
\text { as per the entrepreneurial situation c7 }\end{array}$ \\
\hline \multirow[t]{8}{*}{$\begin{array}{l}\text { Capacity } \\
\text { building } \\
\text { policies }\end{array}$} & $\begin{array}{l}\text { Increasing } \\
\text { entrepreneurship } \\
\text { course C4 }\end{array}$ & $\begin{array}{l}\text { Establishing entrepreneurship course c85, } \\
\text { compulsory practical course c75 }\end{array}$ \\
\hline & $\begin{array}{l}\text { Compiling related } \\
\text { textbook } \mathrm{C} 5\end{array}$ & $\begin{array}{l}\text { Compiling entrepreneurship } \\
\text { education textbook c45 }\end{array}$ \\
\hline & $\begin{array}{l}\text { Practical ability } \\
\text { exercise C6 }\end{array}$ & $\begin{array}{c}\text { Productive internship c79, pay attention } \\
\text { to the educational value of } \\
\text { entrepreneurial practice c14 }\end{array}$ \\
\hline & $\begin{array}{l}\text { Academic evaluation } \\
\text { reform } \mathrm{C} 7\end{array}$ & $\begin{array}{l}\text { Reforming the way of } \\
\text { academic evaluation c } 47\end{array}$ \\
\hline & $\begin{array}{c}\text { Classified } \\
\text { management C8 }\end{array}$ & $\begin{array}{l}\text { Carrying out entrepreneurship teaching } \\
\text { by classification c30 }\end{array}$ \\
\hline & $\begin{array}{l}\text { Teaching hardware } \\
\text { facilities C9 }\end{array}$ & $\begin{array}{l}\text { Constructing hardware facilities conducive } \\
\text { to entrepreneurship education c48 }\end{array}$ \\
\hline & $\begin{array}{l}\text { Tax reduction and } \\
\text { exemption and } \\
\text { subsidy } \mathrm{C} 10\end{array}$ & $\begin{array}{l}\text { Preferential tax for start-ups c82, } \\
\text { enjoying a fee and tax deduction of } \\
8000 \text { yuan within } 3 \text { years c } 27\end{array}$ \\
\hline & $\begin{array}{l}\text { Reducing } \\
\text { entrepreneurial } \\
\text { obstacles C11 }\end{array}$ & $\begin{array}{l}\text { R\&D expenses included in the current loss c } 81 \text {, } \\
\text { lowering market access threshold c18 }\end{array}$ \\
\hline \multirow{4}{*}{$\begin{array}{l}\text { Entrepreneurial } \\
\text { incubation } \\
\text { policies }\end{array}$} & $\begin{array}{l}\text { Institutional } \\
\text { guarantee } \mathrm{C} 12\end{array}$ & $\begin{array}{l}\text { Flexible academic system c51, setting up } \\
\text { entrepreneurship education credits c52 }\end{array}$ \\
\hline & $\begin{array}{l}\text { Financial } \\
\text { support C13 }\end{array}$ & Petty loan c20, venture fund c21 \\
\hline & $\begin{array}{l}\text { Intellectual s } \\
\text { upport C14 }\end{array}$ & $\begin{array}{l}\text { Implementing entrepreneurship training } \\
\text { for university students } c 23\end{array}$ \\
\hline & $\begin{array}{l}\text { Hardware } \\
\text { support C15 }\end{array}$ & $\begin{array}{c}\text { Facilitating entrepreneurial } \\
\text { premise c17 }\end{array}$ \\
\hline
\end{tabular}




\begin{tabular}{|c|c|c|}
\hline \multirow{4}{*}{$\begin{array}{l}\text { Faculty incentive } \\
\text { policies }\end{array}$} & $\begin{array}{l}\text { Entrepreneurship theme } \\
\text { scientific research C16 }\end{array}$ & $\begin{array}{l}\text { Recommending scientific research projects } \\
\text { in colleges and universities c44 }\end{array}$ \\
\hline & $\begin{array}{l}\text { Reform of assessment } \\
\text { and promotion } \mathrm{C} 17\end{array}$ & $\begin{array}{l}\text { Achievements of researchers participating in } \\
\text { entrepreneurship used in job competition c } 89\end{array}$ \\
\hline & $\begin{array}{l}\text { Increasing teachers' } \\
\text { return on } \\
\text { achievements } \mathrm{C} 18\end{array}$ & $\begin{array}{l}\text { Scientific and technological achievements } \\
\text { transformation reward c } 68 \text {, reward for } \\
\text { individuals without affecting the entity c } 69\end{array}$ \\
\hline & $\begin{array}{l}\text { Motivating teachers' } \\
\text { entrepreneurial } \\
\text { action C19 }\end{array}$ & $\begin{array}{l}\text { Encouraging researchers to leave their } \\
\text { posts to start their businesses c } 88\end{array}$ \\
\hline \multirow{4}{*}{$\begin{array}{l}\text { Environment } \\
\text { optimization } \\
\text { policies }\end{array}$} & $\begin{array}{l}\text { Property rights } \\
\text { protection C20 }\end{array}$ & $\begin{array}{l}\text { Establishing intellectual property } \\
\text { trading platform c84 }\end{array}$ \\
\hline & $\begin{array}{l}\text { Economic structure } \\
\text { adjustment } \mathrm{C} 21\end{array}$ & Adjusting the structure c 94 \\
\hline & $\begin{array}{l}\text { Resource sharing } \\
\text { mechanism C22 }\end{array}$ & $\begin{array}{l}\text { Integration of industry and education c78, } \\
\text { the introduction of enterprise } c 79\end{array}$ \\
\hline & $\begin{array}{l}\text { Action coordination } \\
\text { mechanism C23 }\end{array}$ & $\begin{array}{l}\text { Government departments form a joint } \\
\text { meeting mechanism c } 670\end{array}$ \\
\hline
\end{tabular}

and other market subjects, and mobilize enterprises and other educational subjects to participate in entrepreneurship education in colleges and universities, in order to form a benign interaction and resource cycle among universities, government and enterprises.

2) There exist deficiencies in the application of entrepreneurial incubation policy and incentive policy

The entrepreneurial incubation policies directly target university students. Various government departments offer special tax and fee deductions and corresponding entrepreneurial subsidies, and provide various facilitation measures and ways to reduce the risks and difficulties facing university students in starting a business. Also, university students are provided with entrepreneurial mentors and think-tank services, as well as rent-free or low-rent venues at the initial stage of starting a business. University students' entrepreneurial projects enjoy a set of services from registration, accounting agency, legal affairs to financing, which stimulate university students' entrepreneurial willingness and entrepreneurial practice. However, there is a lack of corresponding policies for joint entrepreneurship by teachers and students in the existing policies. University teachers, as the most important intellectual support for students' entrepreneurial practice, have not been valued correspondingly by the entrepreneurial incubation policy. The absence of university teachers undoubtedly increases the difficulty for university students to carry out entrepreneurial practical activities, which is not conducive to the development of entrepreneurship education in colleges and 
universities in the long run.

Capacity building policies provide various supports for college and university teachers' lack of capacity in carrying out entrepreneurship education, and reduce their pressure when carrying out entrepreneurship education. The main method is training and meeting participation, with emphasis on the construction of entrepreneurship education courses, and policies that lack practical training, practical combat and interaction and exchange with various mentors. Besides, there is a lack of capacity building programs and measures for university administrators in the existing policies. As the most important organization to carry out entrepreneurship education, managers' cognition of colleges and universities will directly determine the way and intensity of resource allocation in colleges and universities. Corresponding capacity building should be given according to the characteristics of this group.

3) The less targeted incentive policy, despite its rich content, is difficult to effectively mobilize the enthusiasm of teachers

Incentive policies include four aspects, i.e., carrying out thematic scientific research, reform of assessment and promotion, increasing teachers' return on achievements, and motivating teachers' entrepreneurial action. Among them, the thematic scientific research shares consistent job requirements with university teachers, which cannot embody the particularity of entrepreneurship education in colleges and universities. It seems the policies such as reform of assessment and promotion, increasing teachers' return on achievements, and motivating teachers' entrepreneurial action give those who take actions room for choice in terms of content, but due to the unclear core content and the limitation of the mechanism and system, it is difficult for college and university teachers to obtain opportunities for professional development according to the too broad terms, and it is difficult to effectively mobilize teachers' enthusiasm. Teachers are the key factors to improve the quality of entrepreneurship education in colleges and universities. The government should provide an operational policy basis for the specific problems facing teachers, such as specifying the specific implementation methods of classified assessment.

\section{Acknowledgements}

This work was financed by the MOE (Ministry of Education in China) Project of Humanities and Social Sciences (grant No. 18JDSZK095).

\section{Conflicts of Interest}

The author declares no conflicts of interest regarding the publication of this paper.

\section{References}

Busenitz, L. W., Gomez, C., \& Spencer, J. W. (2000). Country Institutional Profiles: Unlocking Entrepreneurial Phenomena. Academy of Management Journal, 43, 994-1003.

Chen, X. M. (1999). The Ideas and Methods of Grounded Theory. Educational Research 
and Experiment, No. 4, 58-63+73.

Dong, Z. X. (2012). An Analysis on Entrepreneurship Education in Chinese Universities between 1999-2010. Journal of Beijing University of Aeronautics and Astronautics (Social Science Edition), 25, 107-110.

Etzkowitz, H. (2008). The Triple Helix: University-Industry-Government Innovation in Action. New York: Routledge. https://doi.org/10.4324/9780203929605

Gephart, R. P. (2004). Qualitative Research and the Academy of Management Journal. Academy of Management Journal, 47, 454-462. https://doi.org/10.5465/amj.2004.14438580

Glaser, B. G., \& Strauss, A. L. (1967). The Discovery of Grounded Theory: Strategies for Qualitative Research. Chicago: Aldine Publishing Company.

Krücken, G. (2017). Paul J. DiMaggio und Walter W. Powell: The Iron Cage Revisited: Institutional Isomorphism and Collective Rationality in Organizational Fields. Schlüsselwerke der Wirtschaftssoziologie, 48, 195-196.

Scott, W. R. (1995). Institutions and Organizations. Thousand Oaks, CA: Sage.

Xue, L. (2018). Review and Reflection on China's Science and Technology Innovation Policy in the Past 40 Years. Studies in Science of Science, 36, 2113-2115+2121.

Zhu, W. (2018). Policy Design Theory: Revival, Obstacles and Development. Social Sciences in Nanjing, No. 5, 75-81+88. 